\title{
APLICAÇÕES DO CONFORTO AMBIENTAL NO AMBIENTE CONSTRUÍDO: O CASO DO CENTRO DE PINHEIROS, JUNTO A ESTAÇÃO FARIA LIMA
} APPLICATIONS OF ENVIRONMENTAL COMFORT IN THE BUILT ENVIRONMENT: THE CASE OF THE HEART OF PINHEIROS DISTRICT, SURROUDING FARIA LIMA SUBWAY STATION

\section{Milene Mendes Mamede}

Aluna especial na disciplina Projeto Sustentável na Faculdade de São Paulo - FAU-USP, graduada em Arquitetura e Urbanismo na Pontifícia Universidade Católica de Campinas.

e-mail: milene@mamede.com.br

\section{RESUMO}

A falta de planejamento urbanístico nos grandes centros, ocasionou em um crescimento desordenado como a falta de áreas verdes deixando de proporcionar um conforto climático nas calçadas, espaço onde milhares de pedestre frequentam constantemente e não possuem qualquer conforto. Essa pesquisa tem como objetivo mostrar como é a qualidade do conforto climático ao pedestre em um percurso na região central de Pinheiros. O método de trabalho consistiu nas aplicações de simulações feitas por softwares e por fotos registradas também nesse percurso, para verificar o sombreamento e as áreas de intensa insolação existentes nas diversas estações do ano. Com essa aplicação foi possível verificar a necessidade do conforto ambiental, e da inserção de infraestrutura verde nas calçadas e praças. E com essas aplicações relatar o quão é importante atingir o conforto ambiental no ambiente construído para a qualidade de vida.

Palavras-chave: Conforto climático; infraestrutura verde; insolação; desenho ambiental. 


\begin{abstract}
The lack of urban planning in the major centers has led to an uncontrolled growth such as the lack of green areas, not providing climatic comfort on the sidewalks, space where thousands of pedestrians constantly attend, having no comfort. This research aims to show how the quality of the climatic comfort to the pedestrian in the central region of Pinheiros District is. The working method consisted of applying simulations made by software and photos therein recorded, aiming to check the shading and the areas of intense insolation existing in the different seasons. With such method, it was possible to verify the need for environmental comfort and the insertion of green infrastructure in sidewalks and squares. It was also possible to report how important is to achieve environmental comfort in the environment built for the quality of life.
\end{abstract}

Keywords: Environmental comfort; green infrastructure; climatic comfort; insulation; environmental design.

\title{
INTRODUÇÃO
}

Define-se o conforto ambiental quando há um adequado desenho urbano, alinhado ao desenho ambiental e as estratégias de infraestrutura verde criando áreas sombreadas, com conforto climático, temperaturas adequadas, tornando a permanência do pedestre em seu trajeto e no ambiente confortáveis proporcionando melhor qualidade de vida.

Essa pesquisa visa mostrar como é a qualidade do conforto climático ao pedestre em um percurso escolhido de uma centralidade inserida no bairro de Pinheiros.

Delimita-se a área de estudo dentro de três trechos conforme mostrado na figura abaixo. O primeiro trecho inicia-se no Terminal Pinheiros até o Metro Faria Lima, passando pela Rua Capri, e Rua Pais Leme. O Segundo trecho no Metro Faria Lima até Av. Rebouças, passando pela Av. Brigadeiro Faria Lima. O terceiro trecho da Av. Brigadeiro Faria Lima a estação ferroviária Hebraica-Rebouças passando pela Av. Eusébio Matoso. 


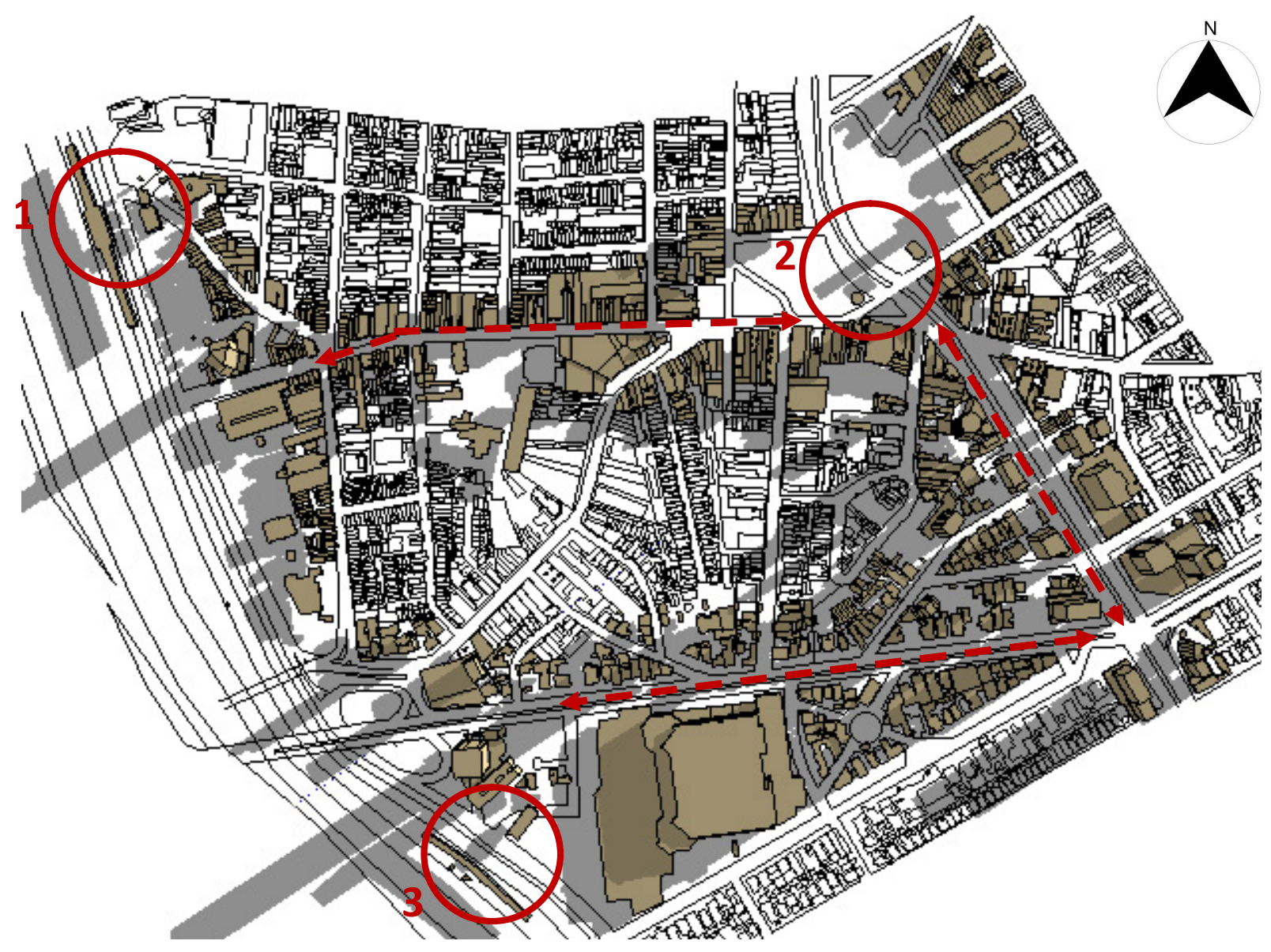

Figura 1 - Delimitação das áreas de estudo

1. Terminal Pinheiros

2. Metrô Faria Lima

3. Av. Rebouças à estação de trem Hebraica Rebouças

O local de estudo foi escolhido por ser uma imponente centralidade de São Paulo, com problemas quanto a qualidade do espaço, em uma área de intenso fluxo de pedestre que transitam entre estações com transporte público.

Uma região com muitos pontos de trabalho, comercio, serviço, ou seja, uma região bem relevante quanto ao intenso tráfico de pessoas que transitam sem conforto climático, sobre o sol em alguns lugares ou sobre as sombras cinzas em outro, sem sombras de qualidade fornecidas pelas áreas verdes.

Esse trabalho foi dividido em: analisar o contexto histórico da região de Pinheiros, introduzir conceitos para ressaltar a importância da infraestrutura verde na qualificação 
da vida das pessoas e apresentar simulações que comprove o quanto essa região está exposta a intensa insolação nas diferentes estações do ano. Esse sol poderia ser muito favorável se houvesse uma boa arborização, uma vez que ele seria convertido num ambiente agradável iluminado e com bom conforto térmico.

As imagens postas nesse trabalho relatam a realidade atual desse ambiente, que demonstram mais uma vez a necessidade de um bom planejamento para essa região.

\section{O BAIRRO DE PINHEIROS}

São Paulo é uma cidade em constante transformação, e a Marginal Pinheiros sofre isso desde 1970, segundo Alexandre (2010) a descentralização vem transformando a paisagem urbana da cidade, e nesse caso as antigas áreas de várzea do rio tornaram-se espaços de intensa valorização imobiliária. Desta forma a Marginal Pinheiros tornou-se um dos novos centros de negócios da cidade, porem o processo de urbanização recebeu pouco investimento público e falta de infraestrutura nessas áreas é visível.

Até a década de 1970, o vale de Pinheiros ainda não era ocupado e suas áreas de várzea do rio se mantinham naturais e preservadas, entremeadas por bairros residenciais de médio e baixo padrão, apenas em alguns poucos trechos nas proximidades das pontes Cidade Universitária, Cidade Jardim, Eusébio Matoso e Morumbi havia bairros residenciais de elite, urbanizados pela companhia City ${ }^{1}$ no padrão dos bairrosjardim. Nas extremidades norte e sul do rio, próximos ao Rio Tietê e às represas, concentravam-se áreas com grandes glebas de uso industrial e galpões.

Entre as décadas de 1940 e 1970 a empresa Companhia Light, responsável pela gestão dos recursos hídricos de São Paulo, realizou seguidas obras de retificação do Rio Pinheiros, drenando as áreas inundáveis existentes em ambas as margens. Ao final deste período, a Cia. Light, que detinha o monopólio sobre vasta porção da cidade, realizou o parcelamento e venda destas terras, dando início a um novo mercado de terras urbanizáveis ao longo do rio.

\footnotetext{
${ }^{1}$ Cia. City: Empresa fundada em 1912 que participou ativamente do processo urbanístico da cidade de São Paulo.
} 


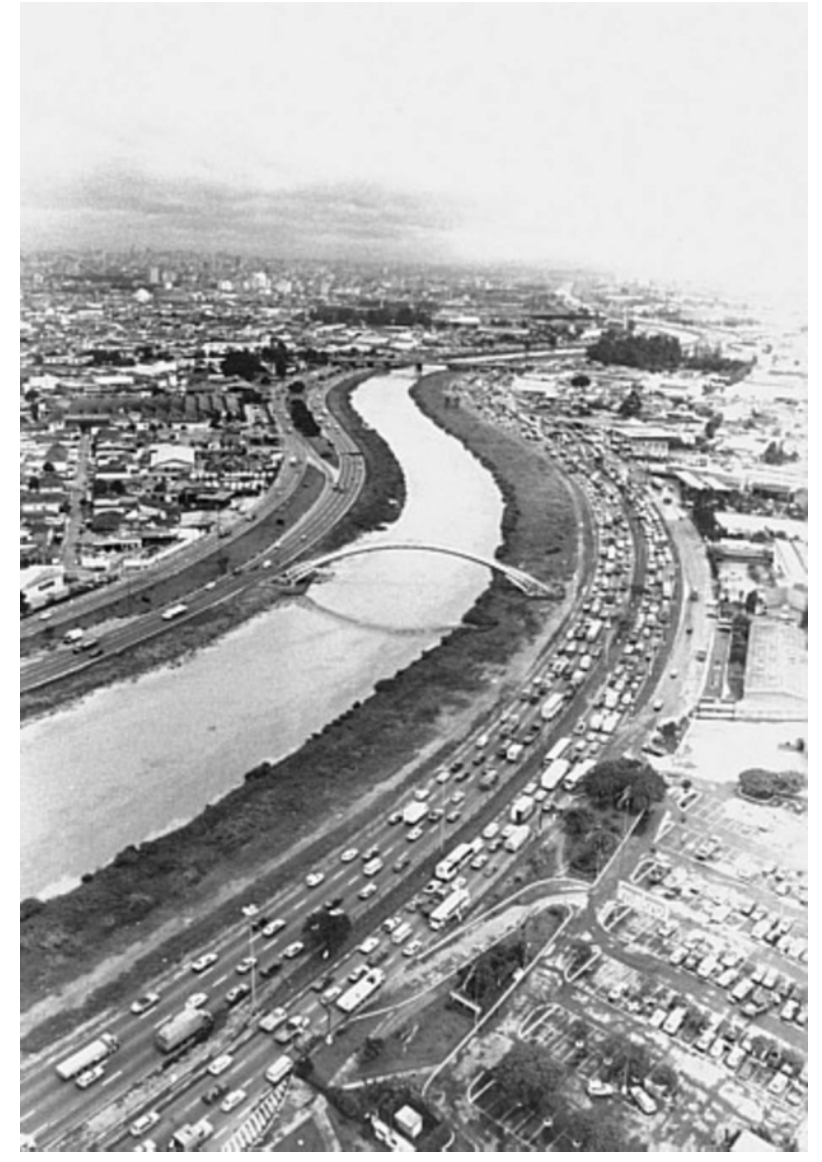

Figura 2 - Em 1970, foi inaugurada a Marginal Pinheiros. Fonte: http://acervo.estadao.com.br/ noticias/lugares, rio-pinheiros,8338,0.htm
No mesmo período, a prefeitura de São Paulo havia executado uma série de obras ampliando a infraestrutura viária dessa região, incluindo a Av. Brigadeiro Faria Lima, inaugurada em 1968; a Av. Luís Carlos Berrini, aberta no início dos anos 1970; e a Marginal Pinheiros cuja construção deu-se ao longo desta década. Atraídos pela oferta de terrenos amplos e baratos, com acesso facilitado pelas novas avenidas, e com anuência da recém-aprovada Lei de Zoneamento de 1972. Nesta zona, presente nas áreas adjacentes aos rios Pinheiros os usos residenciais e os de comércio e serviço são permitidos. Desta forma alguns empreendedores imobiliários começam a investir massivamente na região, transformando completamente a paisagem desta parte da cidade ao longo dos últimos 40 anos.

No início do século XXI, a Marginal Pinheiros é referência de um "novo centro de São Paulo", a área passou a ter um significativo valor expresso em seus arranha-céus, nos numerosos shopping centers e, mais recentemente, em importantes marcos urbanos como a nova ponte Estaiada do Complexo Viário Octávio Frias de Oliveira.

Mas é importante ressaltar que o processo de consolidação da Marginal Pinheiros foi dividido em quatro fases,: A primeira se inicia em 1977 e vai até 1985, considerada o período pioneiro e estrutural.

A segunda fase, vai de 1986 até 1993, os fundos de pensão, expressivo poder de investimento. Neste período ocorre uma entrada de grandes volumes concentrados de investimento, os quais permitiram a construção de uma leva de "mega-empreendimentos" na Marginal Pinheiros durante a década de 1990. 
Entre 1994 e 2000, a terceira fase foi um período caracterizado por novos empreendimentos de grande porte, motivados pelo contexto da globalização e da abertura econômica promovida após o Plano Real. Neste momento, verifica-se o ingresso no mercado imobiliário brasileiro de empresas estrangeiras, o que provocou certa "internacionalização da cultura imobiliária" em São Paulo.

De 2000 em diante foi um momento de estancamento do mercado imobiliário, retirada de boa parte da capacidade de investimento representada pelos fundos de pensão, cujo interesse no mercado imobiliário passa a reduzir-se significativamente neste período. Neste contexto, as taxas de vacância dos escritórios elevam-se significativamente e diversas empresas do mercado imobiliário entram em declínio.

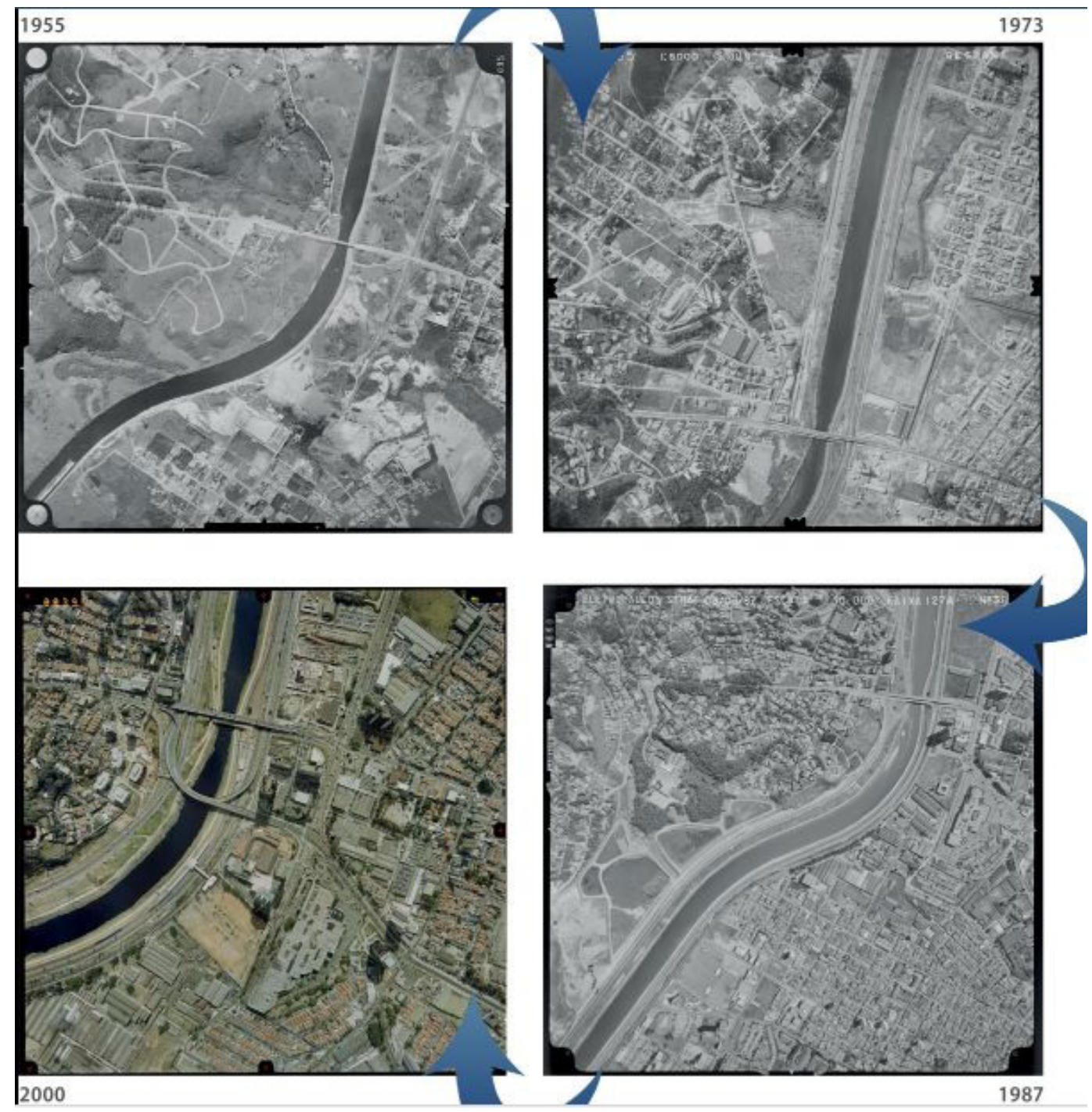

Figura 3 - Imagens do Rio Pinheiros nos anos 1955, 1973, 1987 e 2000.

Fonte: http://mundogeo.com/blog/2010/05/14/rio-pinheiros-em-sao-paulo/ 


\section{LARGO DA BATATA}

O largo da Batata é um bom exemplo de como a mudança de centros comerciais ocorreram na cidade, pois em diferentes momentos na formação do bairro onde está localizado, o Largo sofreu interferências e hoje é uma referência local.

O processo de reprodução do espaço aliado ao capital está gerando novas centralidades que concentram populações de maior poder aquisitivo, e expulsa as populações mais pobres para as periferias da cidade de São Paulo. O projeto de reconversão do Largo da Batata, no centro do bairro de Pinheiros, expulsou uma população ali instalada em função do comercio tradicional da região, como o de lojas populares e camelôs. A revalorização da área se dá justamente para expulsar essa população local, que, segundo as autoridades, degrada seu entorno.

O centro geográfico do bairro de Pinheiros historicamente se concretizou em torno do Largo de Pinheiros e do Largo da Batata. A fundação do bairro de Pinheiros data de 1560, segundo Luisa (2014) era rota para o sul e utilizado como aldeia para os índios, Aldeia Nossa senhora dos Pinheiros da Conceição durante quase três séculos foi núcleo isolado em relação ao aglomerado paulistano. $O$ aldeamento já demostra um caráter de centralidade dentro da cidade de São Paulo.

A partir de 1910, surge um novo momento na produção do espaço de Pinheiros, pessoas de áreas periféricas vão vender seus produtos em São Paulo, quando foi inaugurado o "Mercado Caipira". O bairro começa a constituir um caráter mais importante, tornando um ponto de convergência de produtos, pessoas, fluxos e caminhos. Assim, o Mercado dos Caipiras origina um símbolo da centralidade, e Pinheiros passa a ser visto como um ponto comercial importante dentro da cidade de São Paulo.

O Distrito de Pinheiros entre 1915 e 1929 sofreu uma forte urbanização. E foi a partir de 1910 que recebeu atenção do poder público e assim se integrou materialmente ao restante da cidade. Ocorrem assim grandes obras de aterro, ligando o bairro ao centro da cidade; em 1915 chegou à iluminação elétrica nas ruas. Em 1921 foi transferida para lá a Sociedade Hípica Paulista. E quando retirada iniciou o loteamentos no local, surgindo novas ruas. 


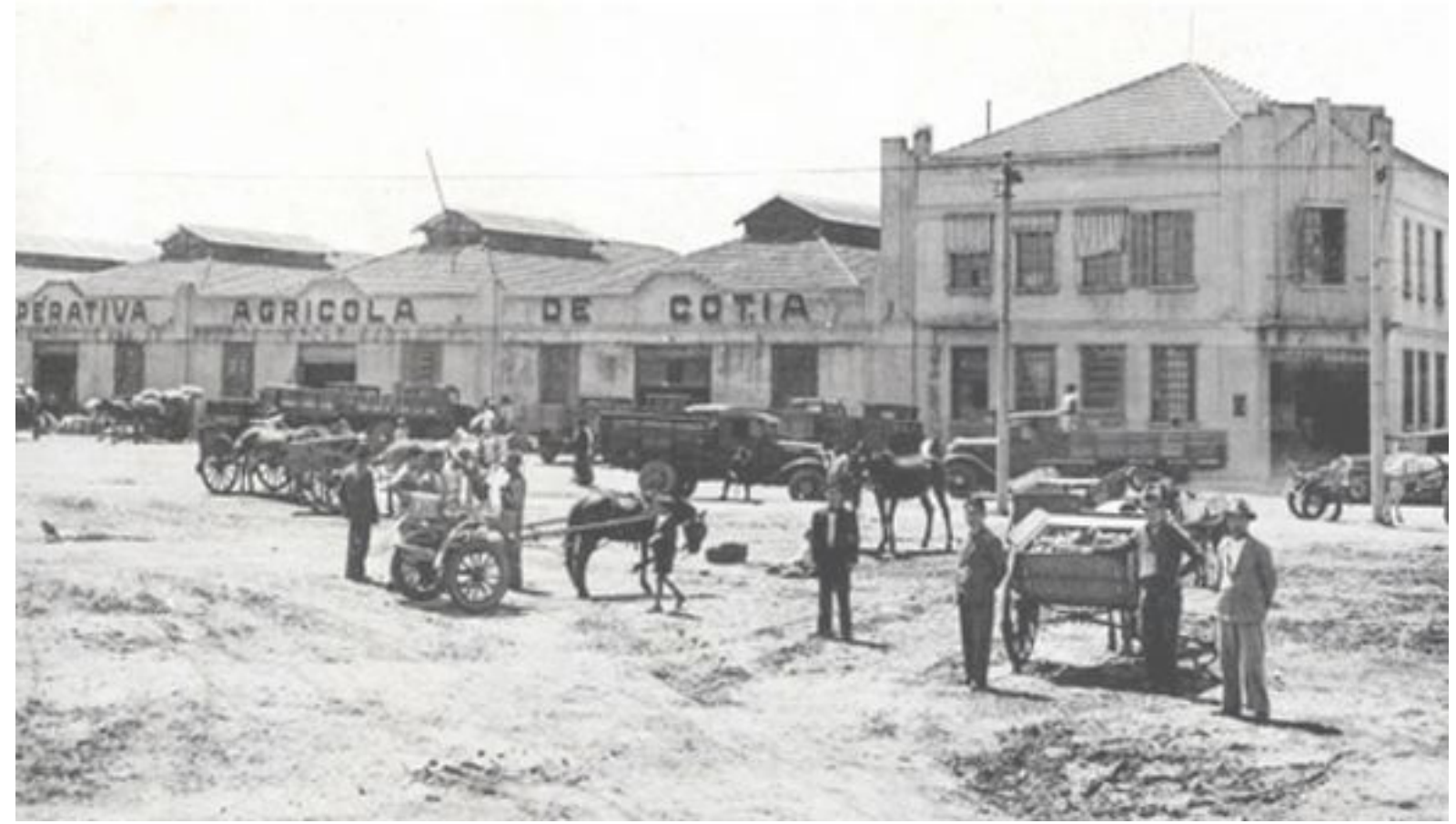

Figura 4 - Mercado onde concentrava os vendedores de batatas próximo a Cooperativa Agrícola de Cotia, década de 1920. Fonte: http://www.saopaulo.com.br/largo-da-batata/

Em 27 de novembro de 1927, através da lei estadual n²249, foi autorizada a canalizar, alargar, retificar e aprofundar os leitos dos rios Pinheiros e seus afluentes, Grande e Guarapiranga; drenando, beneficiando e saneando assim os terrenos situados nas respectivas zonas inundadas. Isso incorporou 25 milhões de quilômetros quadrados de terreno, que começaram a ser aproveitados em 1943, quando terminariam os trabalhos de canalização do rio.

As terras das várzeas só começaram a comportar usos urbanos quando o país passou por fase de modernização, derivado da implementação do Plano de Metas, ao final dos anos 1930.

A partir dos anos 1950, vários melhoramentos foram feitos em Pinheiros, o que já podemos chamar de um primeiro processo de revalorização do bairro, que se realizou através de calçamento de ruas, canalização de córregos e alargamento do largo, etc. Em 1959, a Prefeitura de São Paulo reconhece Pinheiros como um sub-centro, localizado em zona mista. 
Na década de 1960, o bairro passa a ser servido como centro de um grande fluxo de transportes. E no Largo da Batata foi construído o Terminal Pinheiros. A partir dessa época, a região passa a concentrar um comércio popular, ligado ao trânsito de passageiros do Terminal. Ele que concentrará pessoas de renda inferior à do restante do bairro, tornando o Largo degradado segundo o poder público. O Largo da Batata foi ganhando caráter popular, através do comércio para atender não somente os moradores do bairro, mas principalmente aos transeuntes.

No ano de 1968, ocorre a desapropriação de imóveis para a abertura da Avenida Faria Lima, o que mudaria a paisagem.

A Lei de Zoneamento do Munícipio de São Paulo, lei $n^{\circ} 7.805$, de primeiro de Novembro de 1972, que dispõe do parcelamento, uso e ocupação do solo, delimita cinco zonas no distrito de Pinheiros, que mostra como constitui o padrão fundiário e o perfil do bairro. $\mathrm{O}$ zoneamento tinha como função proteger as áreas residenciais de alto padrão.

Na década de 1990, o bairro de Pinheiros era conhecido como centralidade de lazer, com bares e restaurantes, movimentando a vida noturna na Av. Henrique Schaumann, por exemplo. Enquanto isso o Largo era tomado como degradado.

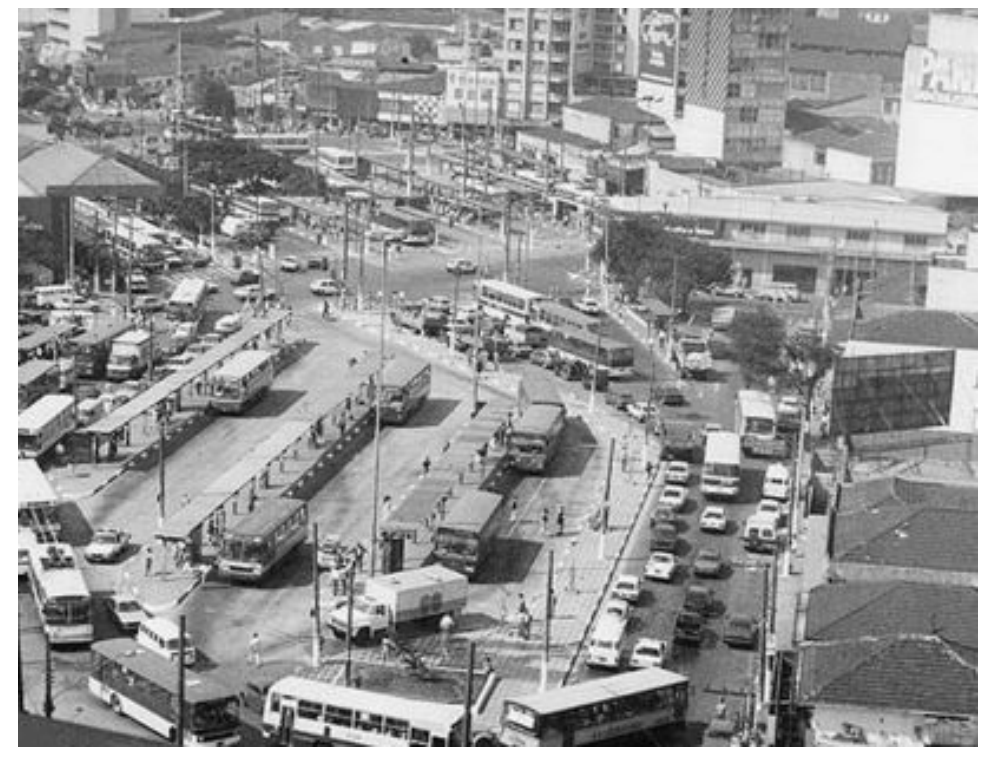

Figura 5 - Largo da Batata, em 1991. Fonte primária: Folha de S. Paulo, 2012. Fonte secundária: MASCARENHAS, P. Luisa. Reconversão Urbana do Largo da Batata: Revalorização e novos conteúdos da Centralidade de Pinheiros. USP, São Paulo 2014.

Em 1995, foi instituída a Operação Urbana Consorciada Faria Lima, através da Lei Ordinária n 11732, de 14 de março de 1995, que trazia como seus objetivos: realizar melhoramentos viários, obras, equipamentos e áreas públicas no perímetro da Ope- 
ração Urbana; melhorar a qualidade de vida, a paisagem urbana e a infraestrutura; incentivar o melhor aproveitamento dos imóveis e estimular o adensamento da região.

A operação previa para este setor o alargamento e prolongamento da Rua Sumidouro e da Avenida Faria Lima; a implementação de um novo Terminal de Ônibus na Rua Capri para remanejar o existente no Largo da Batata; além da execução de intervenção de requalificação urbana no Largo da Batata.

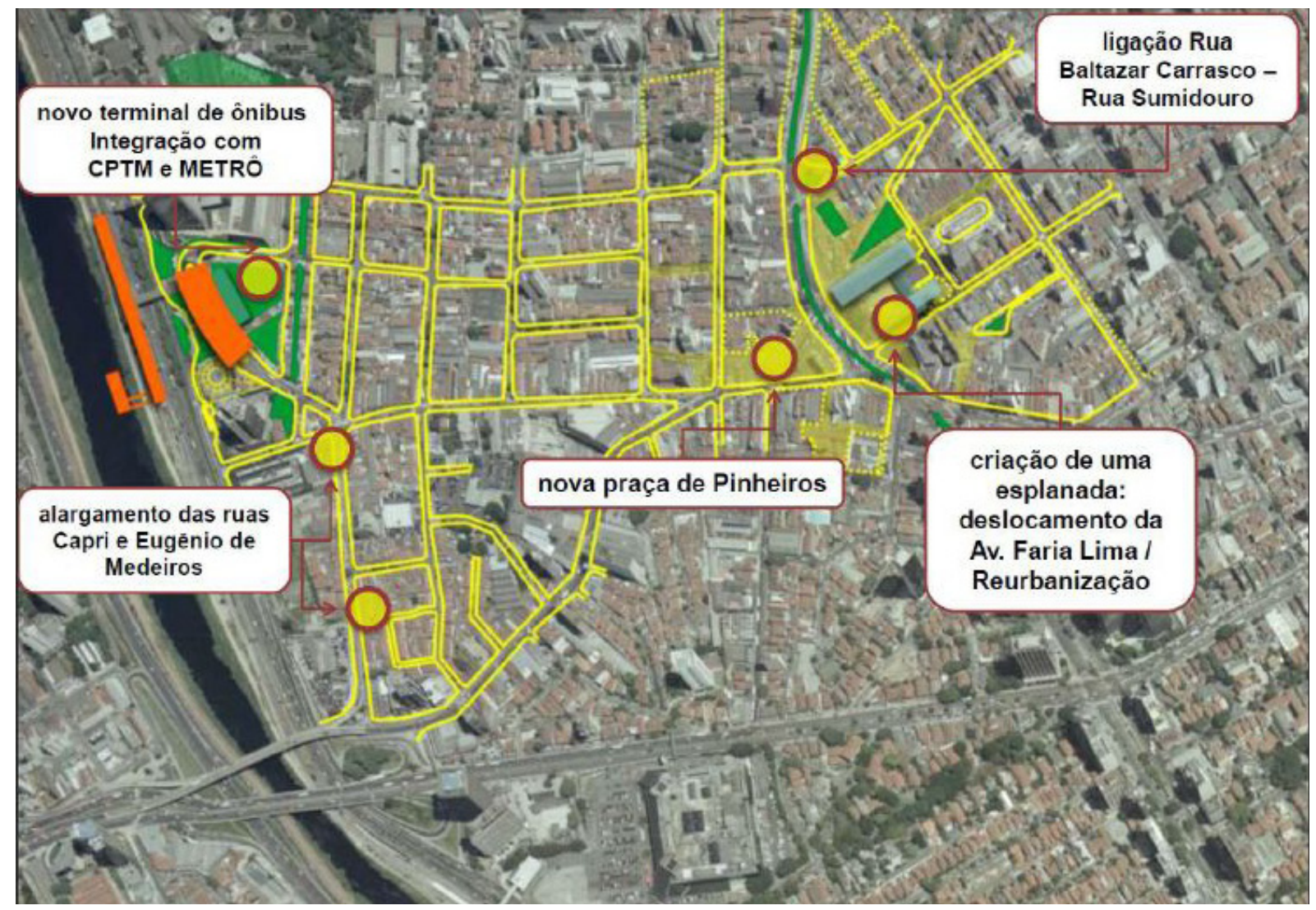

Figura 6 - Programa de investimentos previsto pela 6 ${ }^{a}$ reunião do Grupo de Gestão. Dezembro/2009. Fonte: PMSP, 2012 (MASCARENHAS, 2014).

O Largo da Batata é alvo do projeto da municipalidade denominado Reconversão Urbana, esse projeto está ligado à segunda etapa da Operação Urbana Consorciada Faria Lima, iniciada na década de 1990, que se traduz, de maneira geral em revalorização espacial. Realizou-se um Concurso Público Nacional de Arquitetura e Urbanismo em 2002, promovido pelo Município de São Paulo e pelo Instituto dos Arquitetos de São Paulo (IAB/SP), no qual o projeto vencedor foi o do arquiteto Tito Lívio Frascino. A chamada revitalização da área se dava no âmbito municipal, ao passo que o 
governo estadual planejava a construção da Estação de metrô Faria Lima, da Linha 4 - Amarela. Esta estação requalificou a área, conseguindo assim justificar as desapropriações da área.

As obras de Reconversão foram iniciaram em 2007 e concluídas em 2013. Porem grande parte das intervenções propostas não foi realizado.

O caráter excludente dos processos que se deram na área através da aliança entre poder público, imobiliário e financeiro. As valorizações do lugar e do preço do solo não pouparam somente os vendedores ambulantes, mas proprietários de imóveis. Assim a vida desse lugar foi sendo subtraída e transformada em algo artificial.

O índice FIPE ZAP de Preços de Imóveis Anunciados é o indicador de preços de imóveis produzido em parceria entre FIPE (Fundação Instituto de Pesquisas Econômicas) e o ZAP Imóveis. Segundo esse índice, a variação do preço do metro quadrado para venda de apartamento, casas, comercio e indústria em Pinheiros de janeiro de 2008 a julho de 2013, subiu muito. Mas começa um declínio em comercio e indústria em janeiro de 2013.

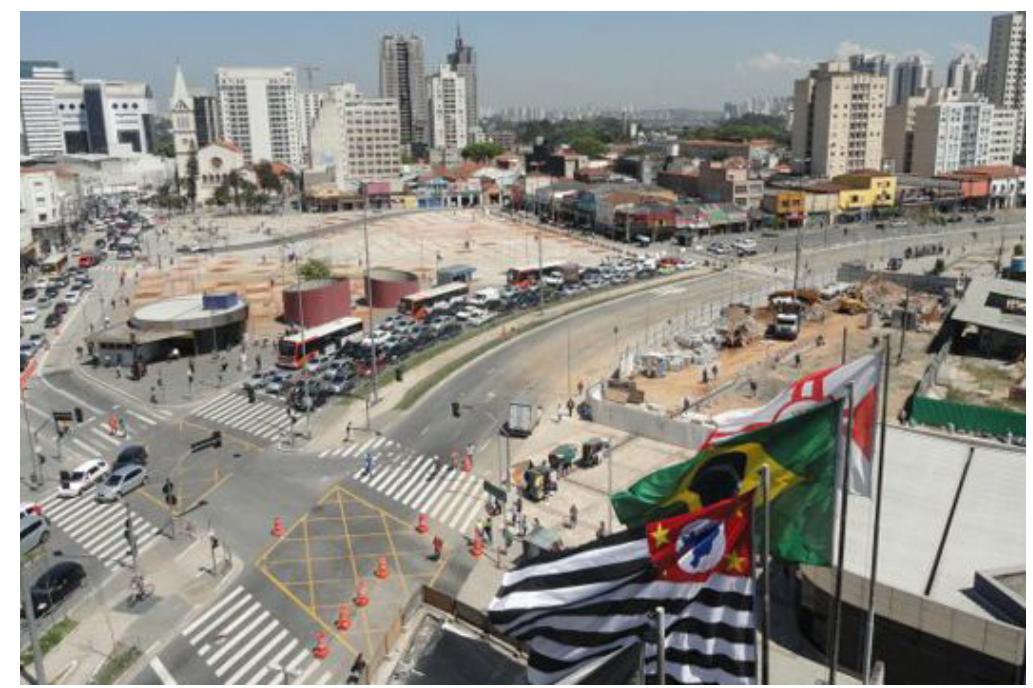

Figura 7 - Largo da Batata, em 2014. Fonte: http://www.saopaulo. com.br/largo-da-batata/

\section{O PAPEL DA INFRAESTRUTURA VERDE NA QUALIDADE DO BAIRRO}

Segundo Gonçalves et. al (2013), a supressão das áreas verdes afeta qualidade de vida da população e potencializa a ocorrência de inundações, poluentes no ar, a alteração do microclima urbano, diminuição da biodiversidade urbana. 
A quantidade e à distribuição das áreas verdes fazem parte da relação de indicadores e parâmetros de avaliação da qualidade de vida das cidades.

A concepção dos espaços vegetados como parte da infraestrutura verde urbana é uma estratégia de estruturação dos espaços naturais, recuperados no processo de planejamento da cidade, já aplicados na Europa e EUA.

A infraestrutura verde é uma contribuição nas funções de base estrutural da cidade.

Dessa mesma forma, a infraestrutura verde pode atuar conjuntamente com outros sistemas, no atendimento ao quadro de funções:

- da mobilidade e acessibilidade, ao direcionar e estruturar eixos de circulação, e ao propiciar rotas específicas ou alternativas para pedestres e ciclistas;

- da drenagem das águas pluviais, regulando o ciclo hídrico, atenuando os picos de cheia e conduzindo as águas com segurança;

- do lazer, da recreação e do convívio social, além de serem espaços de contemplação e percepção estética;

- da manutenção dos processos ecológicos, da biodiversidade e da sustentabilidade dos ecossistemas, colaborando com o aumento da conectividade dos fragmentos naturais.

Cormier (2008) complementa o quadro de funções, com o sistema metabólico da cidade (fluxos infra urbanos de energia e matéria):

A agricultura urbana na utilização das áreas verdes para o atendimento das necessidades básicas de saúde do ser humano.

A infraestrutura verde na criação de conforto térmico nos espaços abertos. Efeito da sombra.

Os elementos que compõem a infraestrutura verde são: os espaços abertos e vegetados, como parques, praças, corredores ecológicos, remanescentes florestais, jardins, tetos verdes, etc., aliados em alguns casos a tecnologias ambientais: tratamento 
com fitorremediação ${ }^{2}$, materiais e pavimentos filtrantes, sistemas de irrigação mais eficiente, placas fotovoltaicas promovendo melhoria na qualidade ambiental e ganhos sociais e econômicos.

Nessa pesquisa define-se o conforto ambiental quando há um adequado desenho urbano, alinhado ao desenho ambiental e as estratégias de infraestrutura verde criando áreas sombreadas, com conforto climático, temperaturas adequadas, tornando a permanência do pedestre em seu trajeto e no ambiente confortáveis proporcionando melhor qualidade de vida.

\section{ESTUDO DE CASO NO CENTRO DE PINHEIROS, ANÁLISE DO CONFORTO AMBIENTAL}

As diferentes estações do ano ocasionam em mudanças significativas no estudo de sombreamento, sendo assim a análise foi realizada nas quatro estações, primavera, verão, outono e inverno. Para otimizar o tempo de estudo, a metodologia escolhida foi com o auxílio do software Sketchup, no qual através de uma base de dados com os gabaritos de altura dos edifícios presentes nos trechos estipulados, esses são modelados. Assim, são geradas imagens de simulação do sombreamento causados pelos edifícios.

As imagens foram geradas em quatro horários diferentes no decorrer do dia (08h00, $12 \mathrm{~h} 00,15 \mathrm{~h} 00,17 \mathrm{~h} 00)$, a fim de obter amostras de todas as situações de sombreamento que podemos encontrar no dia a dia.

Análise da insolação em Pinheiros e do conforto do pedestre nos pontos:

1. Terminal Pinheiros

2. Metrô Faria Lima

3. Av. Rebouças à estação de trem Hebraica Rebouças

\begin{tabular}{|ccc|}
\hline Data do ano & Hemisfério Sul & Hemisfério Norte \\
\hline 20 e 21 de março & Equinócio de Outono & Equinócio de Primavera \\
\hline 22 e 23 de junho & Solstício de Inverno & Solstício de Verão \\
\hline 22 e 23 de setembro & Equinócio de Primavera & Equinócio de Outono \\
\hline 22 e 23 de dezembro & Solstício de Verão & Solstício de Inverno \\
\hline
\end{tabular}

${ }^{2}$ Fitorremediação é uma tecnologia onde se usa plantas para minimizar poluentes do meio ambiente. 


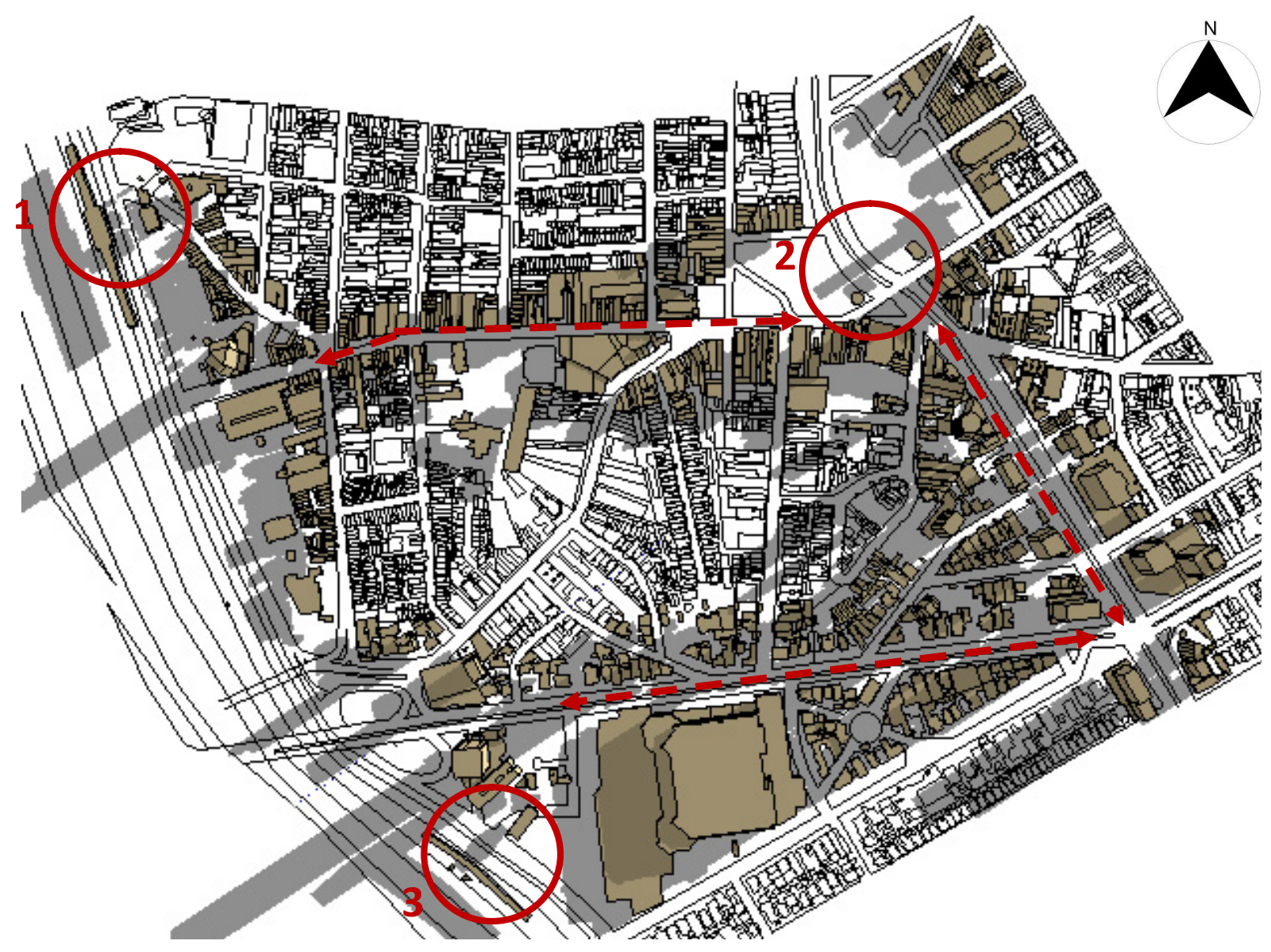

Figura 8 - Trechos analisados

Com os resultados gerados, foi possível fazer o estudo de volumetria da região e ver o sombreamento gerado pelos edifícios no solo, constatando as regiões extremas e precárias de intensa insolação que precisam ser melhoradas e requalificadas para atingir ao conforto ambiental no ambiente construído. Uma solução para recuperar essas áreas precárias seria através do plantio de árvores, criação de áreas verdes, ou seja construir uma infraestrutura verde.

Foram estabelecidas classificações de 0 a 5 para análise da varredura de sombra, nas calçadas e ruas. Considerando zero como o trajeto como nenhum sombreamento e 5 como as áreas bem sombreadas nas diferentes estações do ano.

Como estamos falando de um trajeto que não possui uma aplicação de infraestrutura verde, mesmo com um melhor sombreamento proporcionado pelos edifícios mesmo assim o ambiente não atingirá um bom conforto ambiental e consequentemente um 
melhor conforto climático, isso só seria possível em áreas arborizadas. Ou seja, o nível 5 não foi atingido em nenhuma das situações apresentadas.

Nas figuras 9 e 12, solstício de inverno 21 de junho de 2015, a varredura de sombra proporcionada por simulações mostram o sombreamento gerado pelo ambiente construído às $08 \mathrm{~h} 00$ e as $17 \mathrm{~h} 00$, sendo classificadas como sombreamento de nível 4 perante as outras estações.


Figura 9 - Solstício de inverno 21 de junho às $8 \mathrm{~h}$. Classificação 4.

Figura 12 - Solstício de inverno 21 de junho às $17 \mathrm{~h}$. Classificação 4. 
Na figura 10 as $12 \mathrm{~h} 00$ notam-se o quanto essa área está exposta ao sol, com pouco sombreamento, e a falta de arborização com qualidade nesse trajeto deixa o pedestre ainda mais exposto, sendo classificada como nível 2.

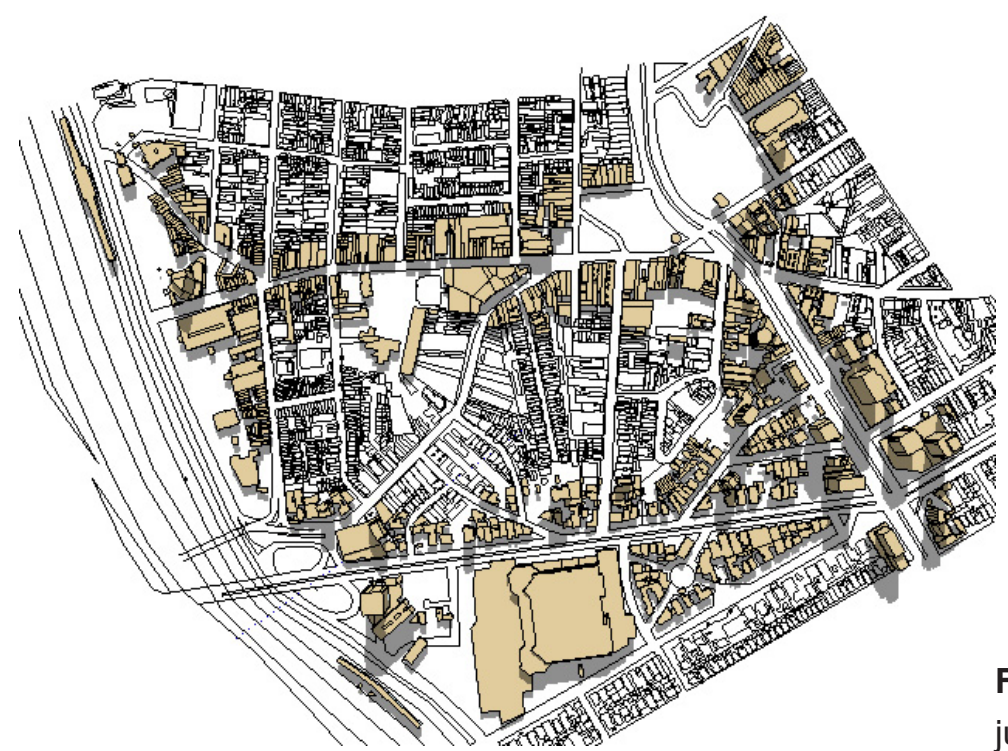

Figura 10 - Solstício de inverno 21 de junho às $12 \mathrm{~h}$. Classificação 2.

A Figura 11 que também compreende ao solstício de inverno as $15 \mathrm{~h} 00$ é caracterizada por um sombreamento classificado como 3 , ou seja há trechos da calçada sombreados e outros expostos ao sol. O que torna o percurso mais atraente, pois o pedestre é nutrido pelo sol e também tem a diferença térmica proporcionada pela sombra, porém como já mencionado sem o conforto climático proporcionado pela infraestrutura verde, o ambiente e o pedestre não são favorecidos por um bom microclima, e não se atinge o conforto ambiental.

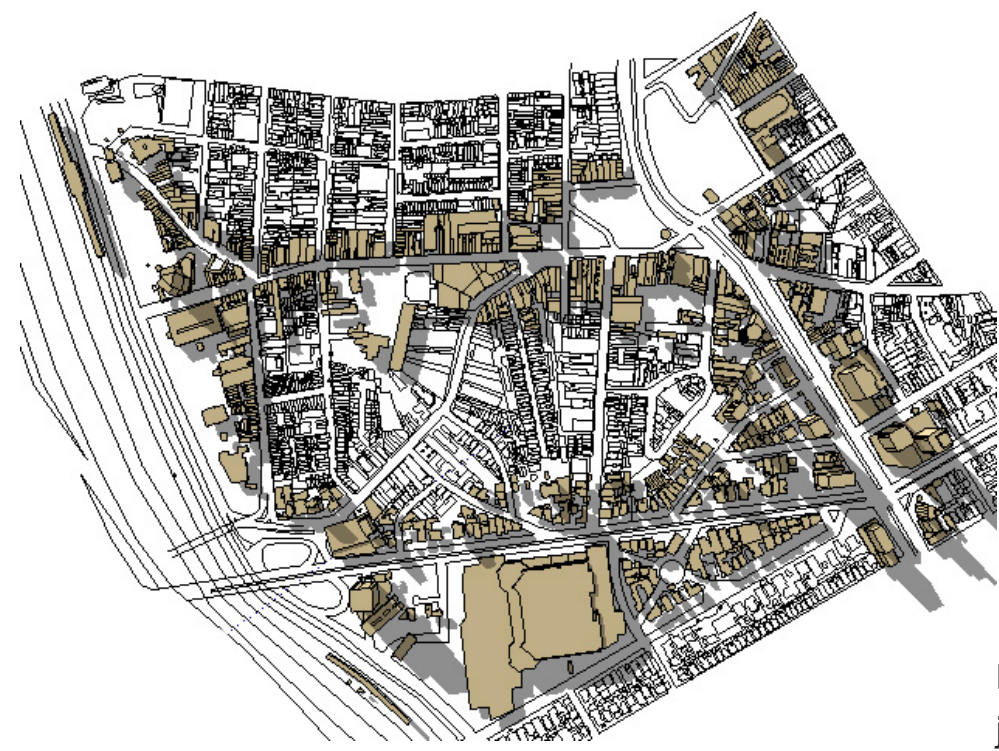

Figura 11 - Solstício de inverno 21 de junho às $15 \mathrm{~h}$. Classificação 3. 
Nas figuras 13, 14 e 15, solstícios de verão 21 de dezembro mostram a área pouco sombreada. Sendo que a figura 14 a classificação é 0 de sombreamento, ou seja, o sol está a cima dos edifícios que não possibilitam algum sombreamento, nisso vimos mais uma vez o quanto o ambiente seria qualificado nesse período se houvesse uma boa arborização.
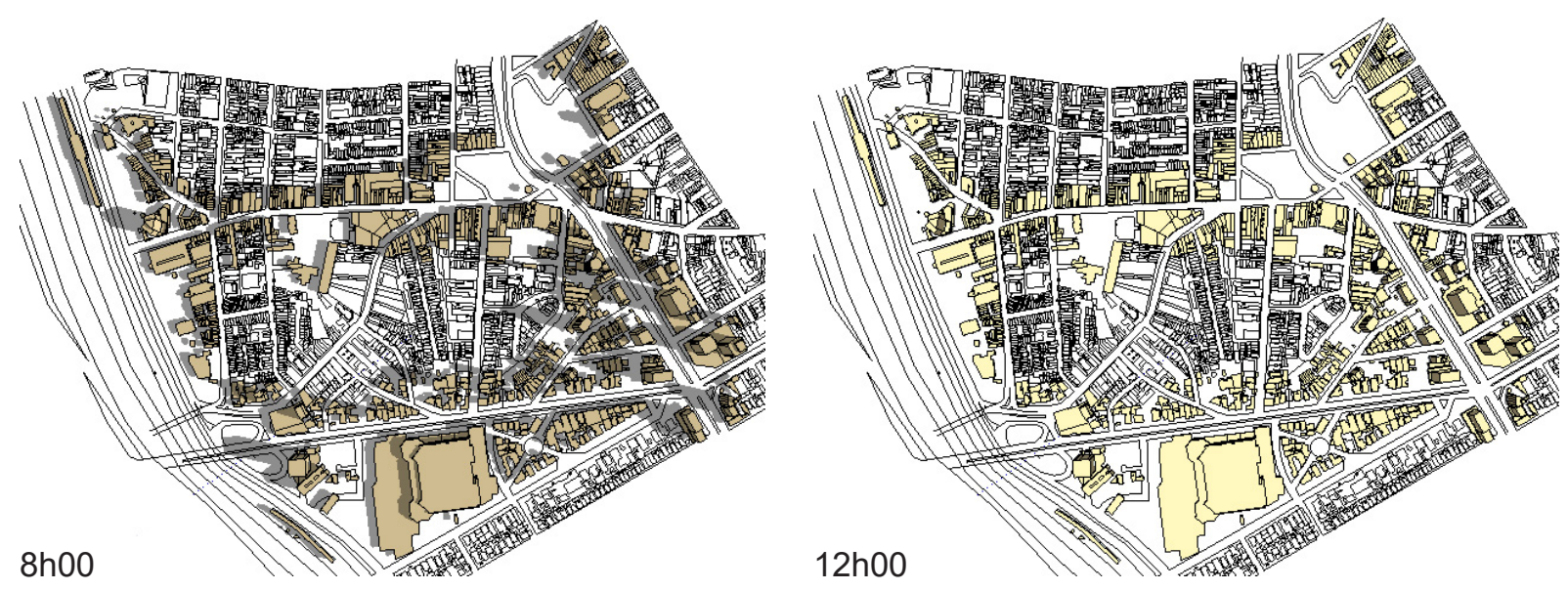

Figura 13 e 14 - Solstício de verão 21 de dezembro. Classificação 2 e 0.

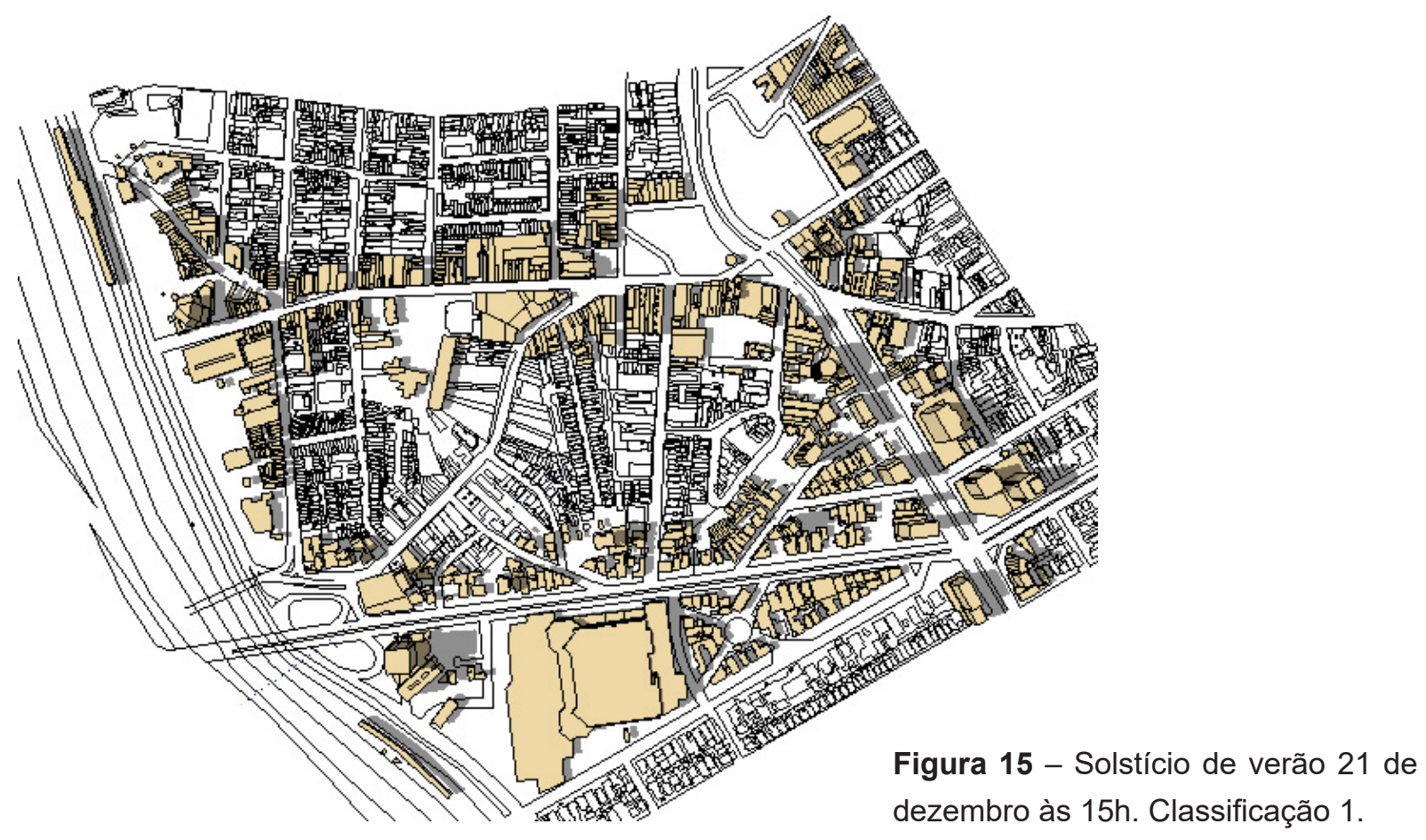

Na figura 16 as $17 \mathrm{~h} 00$ demostra um sombreamento alternado em trechos expostos diretamente ao sol, outros com sombra, classificado como nível 3. 


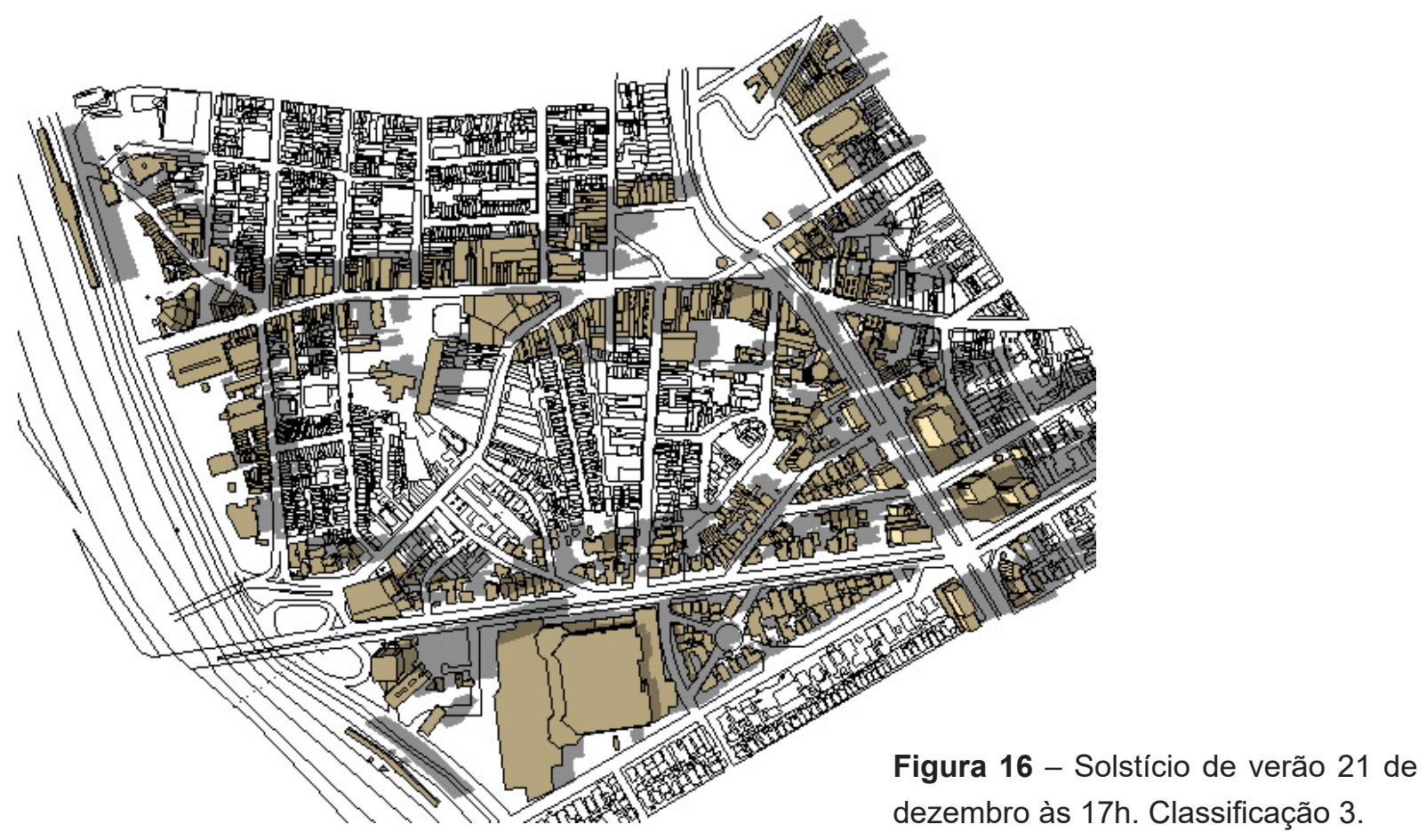

Nas figuras 17, 18, 19 e 20 equinócio de outono 21 de março, a uma similaridade com o solstício de verão, aumentando em 1 nível cada período do dia, tendo assim um pequeno aumento do sombreamento nessa área.



Figura 17 - Equinócio de outono 21 de março às 8h. Classificação 3.

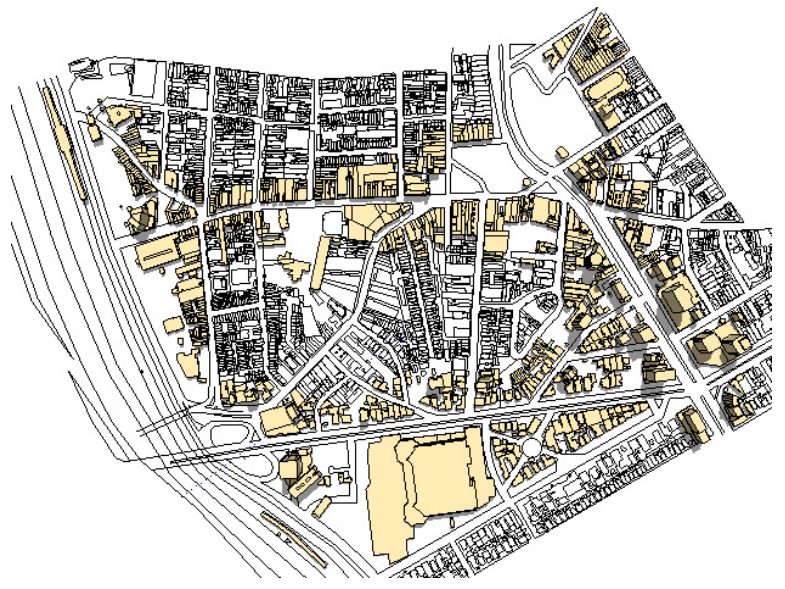

Figura 18 - Equinócio de outono 21 de março às 12h. Classificação 1. 

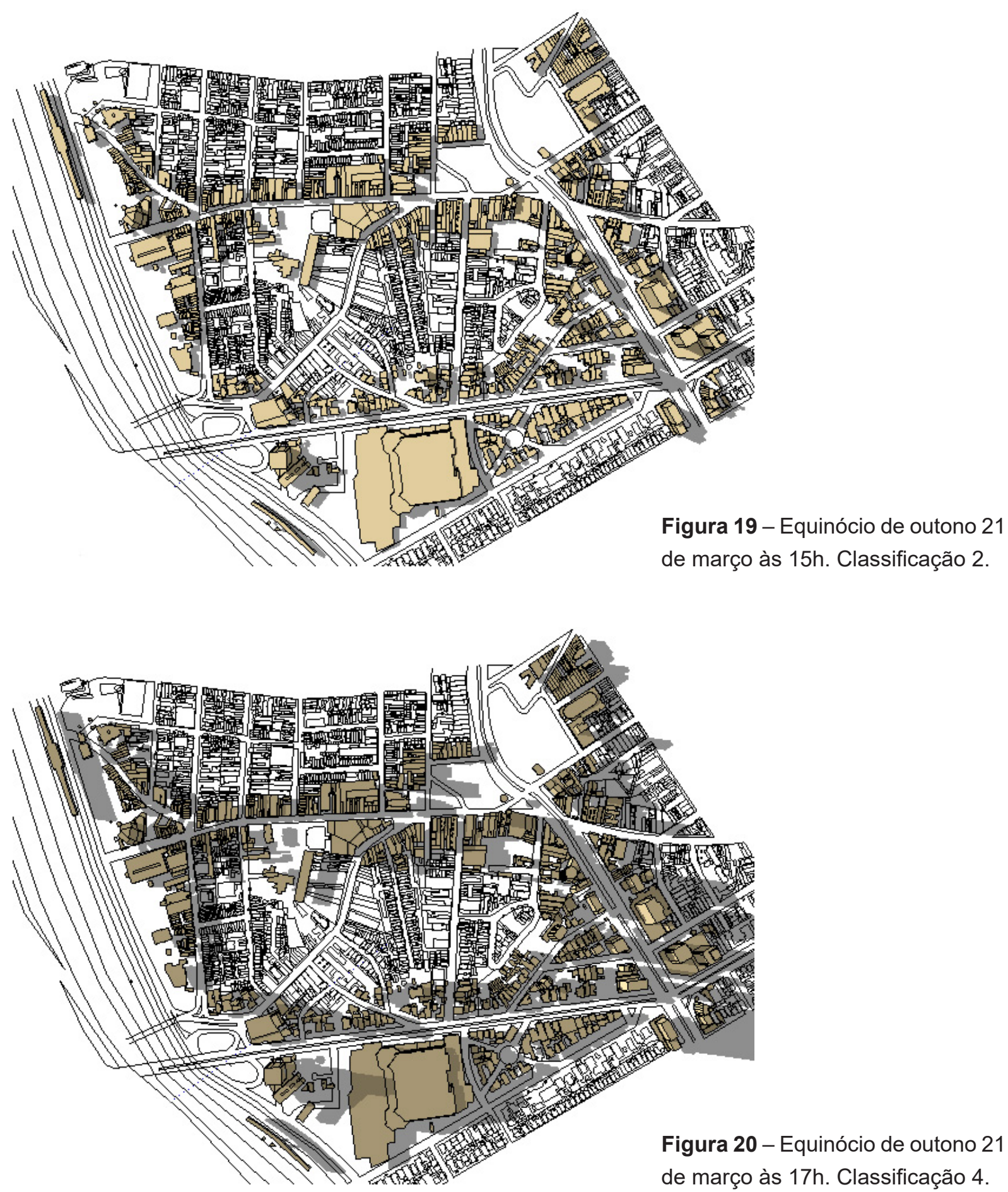

Nas figuras 21, 22, 23 e 24, equinócio de primavera 21 de setembro, apresentam as mesmas classificações do equinócio de outono, equivalendo às mesmas problemát"icas de conforto. 


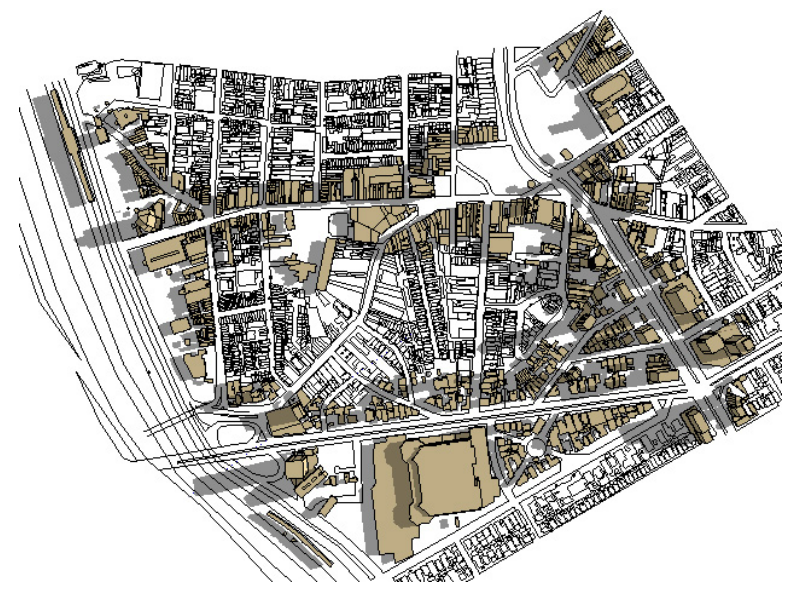

Figura 21 - Equinócio de primavera 21 de setembro às $12 \mathrm{~h}$. Classificação 1.

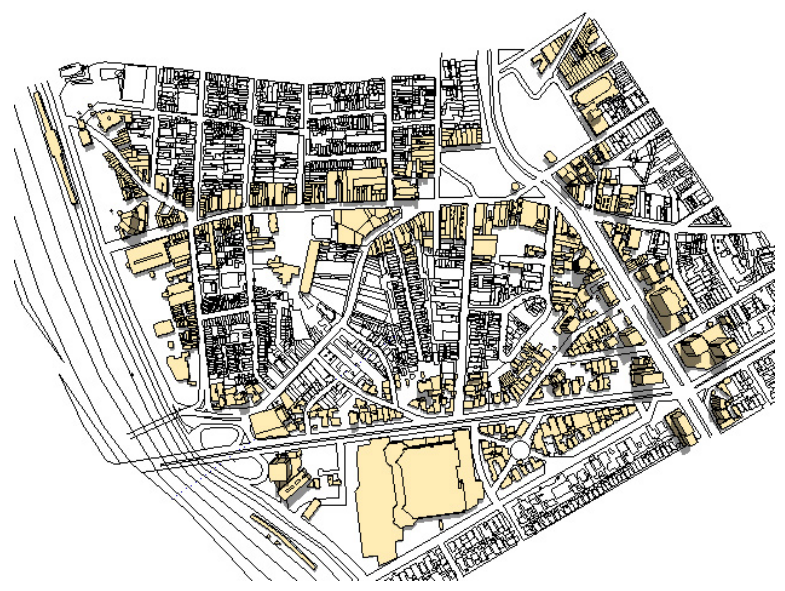

Figura 22 - Equinócio de primavera 21 de setembro às 8 h. Classificação 3.

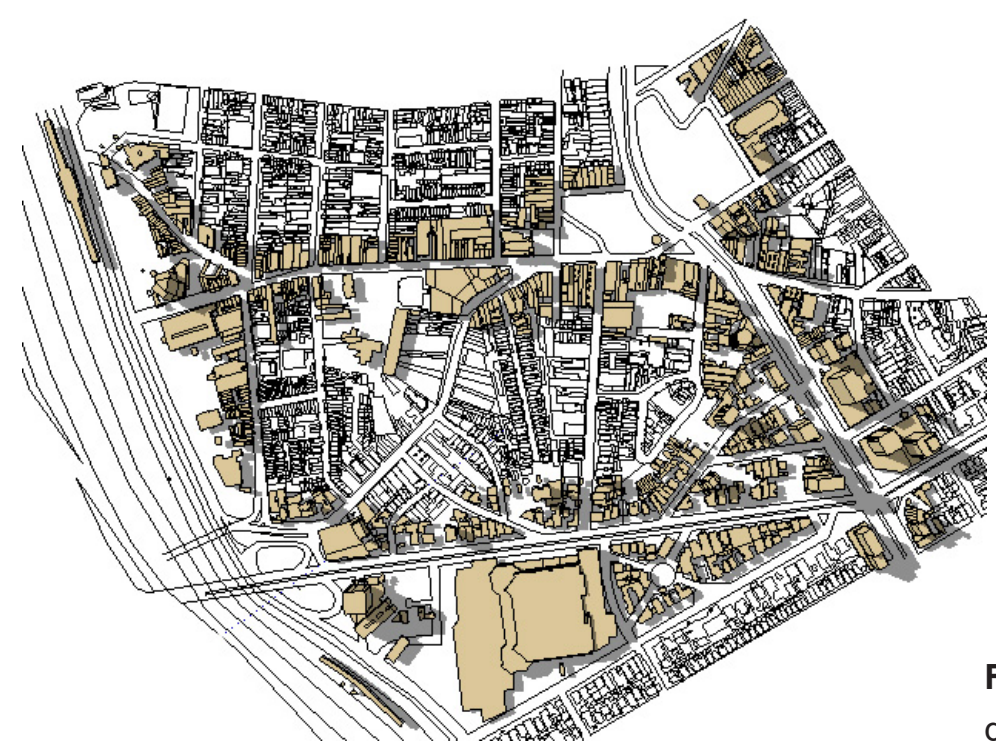

Figura 23 - Equinócio de primavera 21 de setembro às $15 \mathrm{~h}$. Classificação 2 .



Figura 24 - Equinócio de primavera 21 de setembro às $17 \mathrm{~h}$. Classificação 4 . 
Há um melhor sombreamento proporcionado pelo ambiente construído na estação do solstício de inverno atingindo a classificação de 13 pontos, somados os níveis estabelecidos pelos períodos do dia $8 \mathrm{~h}, 12 \mathrm{~h}$ e $15 \mathrm{~h}$ e $17 \mathrm{~h}$. No verão a somatória foi de 6 pontos sendo em geral a estação do ano com menor sombreamento. No outono e primavera a pontuação se manteve em 10 pontos. A Avenida Brigadeiro Faria Lima, na maioria das estações do ano possui sombreamento nas calçadas, devido aos altos edifícios e a pouca arborização do canteiro central.

Nota-se também na Rua Pais Leme, o comercio e edificações em geral existentes são em sua maioria ladeados a calçada e há poucas árvores, isso proporciona algum sombreamento. Já na Avenida Eusébio Matoso o recuo das edificações para acesso de carros e a pouca arborização não proporcionam muito sombreamento, o sombreamento visto é gerado pelos altos edifícios também ali existentes.

Na Avenida Brigadeiro Faria Lima a uma constância maior de sombreamento devido à predominância dos aos altos edifícios, e os trechos arborizados no canteiro central, favorecendo a circulação do pedestre e do ciclista. A existência de ciclovia nesse trajeto aponta um elemento de sustentabilidade na região.

Essa região enquadra uma área de grande uso do pedestre, em destaque na locomoção ao trabalho, aos edifícios comerciais, as áreas de transporte público trem, ônibus, metro.

O gráfico abaixo resume as avaliações atribuídas de sombreamento nos locais analisados.

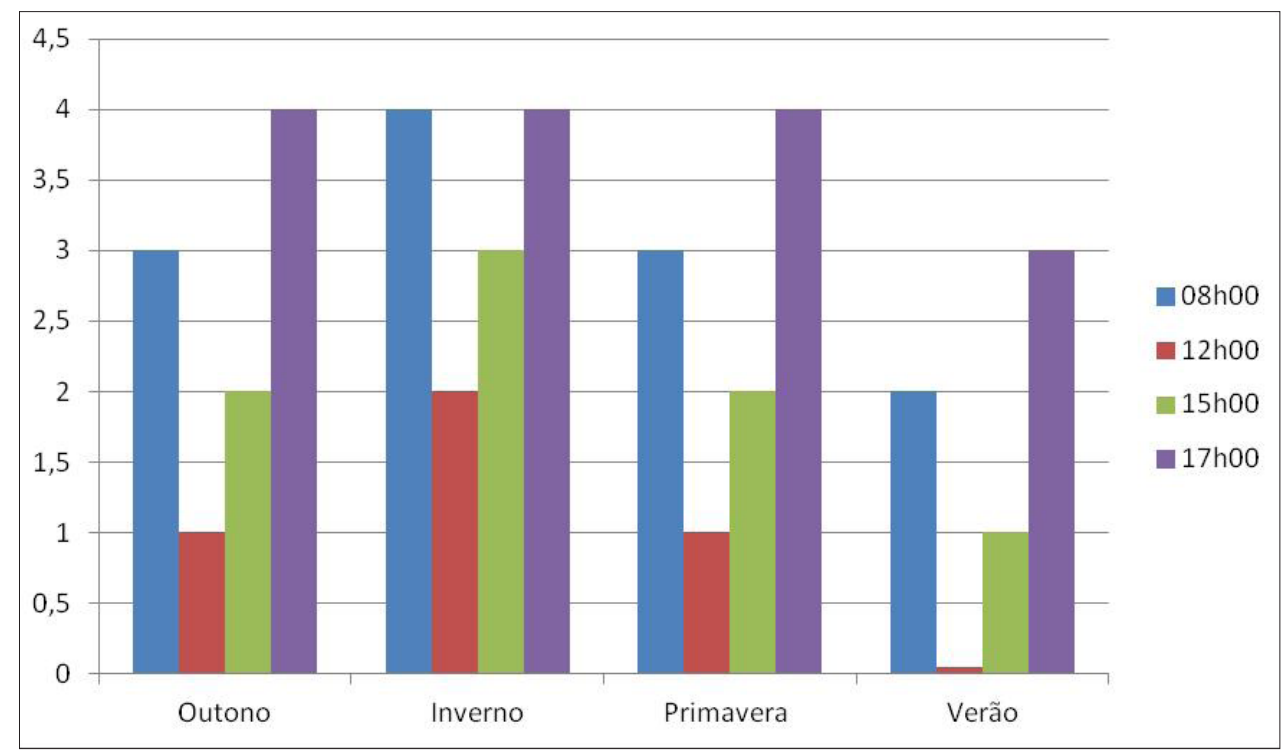

Gráfico 1 - Avaliação do sombreamento 
As imagens abaixo são para constatar os trechos sem ou com pouca insolação nos trechos analisados.

\section{Percurso do terminal Pinheiros ao metro Faria Lima}


Figuras -

25. Rua Capri, saída do terminal Pinheiros;

26. Rua Capri;

27 e 28. Rua Pais Leme;

29. Largo da Batata;

30. Av. Brigadeiro Faria Lima.

Fonte: Fotos da autora

Na imagem 25 a calçada encontra-se descoberta sem qualquer arborização, na imagem 26 há alguns trechos da calçada com arborização e na imagem 27 há um sombreamento proporcionado pelos edifícios comerciais ladeados a calçada.

Imagem 28 e 29 são quadras e o largo aberto com pouca arborização. A imagem 30 mostra o canteiro central, calçada, de acesso ao metro sem sombreamento. 


\section{Percurso do metro Faria Lima à Av. Rebouças}
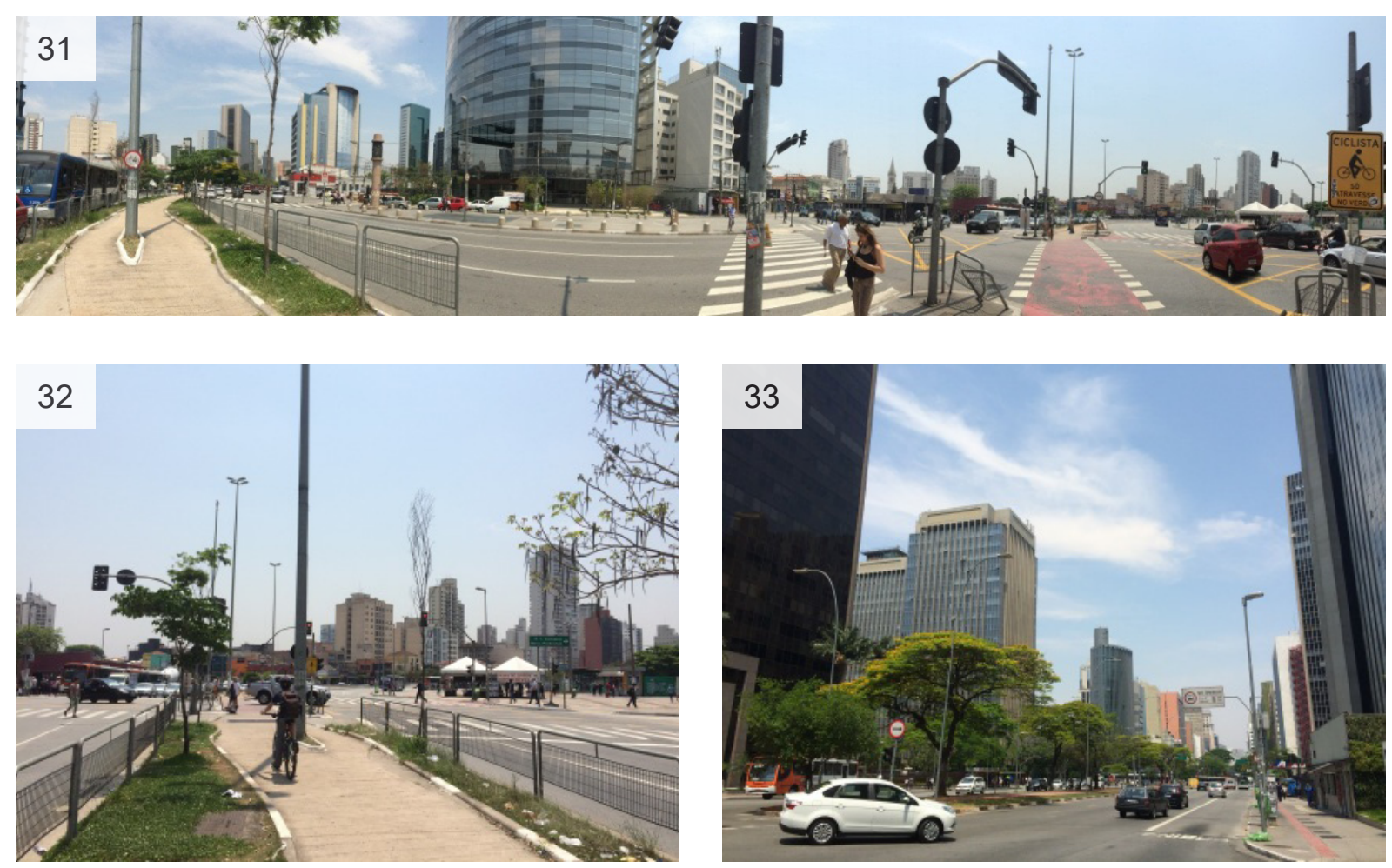

Figuras 31, 32 e 33 - Canteiro central, Av. Brigadeiro Faria Lima. Fonte: fotos da autora

$\mathrm{Na}$ Av. Brigadeiro Faria Lima já à um canteiro central com arborização, e ciclovia, que se traduz em elementos de sustentabilidade, mas nota-se que essa arborização não é suficiente, pois ela não é constante a trechos com pouca arborização. Parte do sombreamento dado nessas calçadas vem dos altos edifícios na avenida, porem ele não é proporcionado em todas as estações do ano e nem em todos os períodos do dia, como visto nas simulações acima. Para um melhor conforto ambiental seria necessário uma área melhor arborizada. 
Percurso da Av. Brigadeiro Faria Lima à estação ferroviária Hebraica-Rebouças
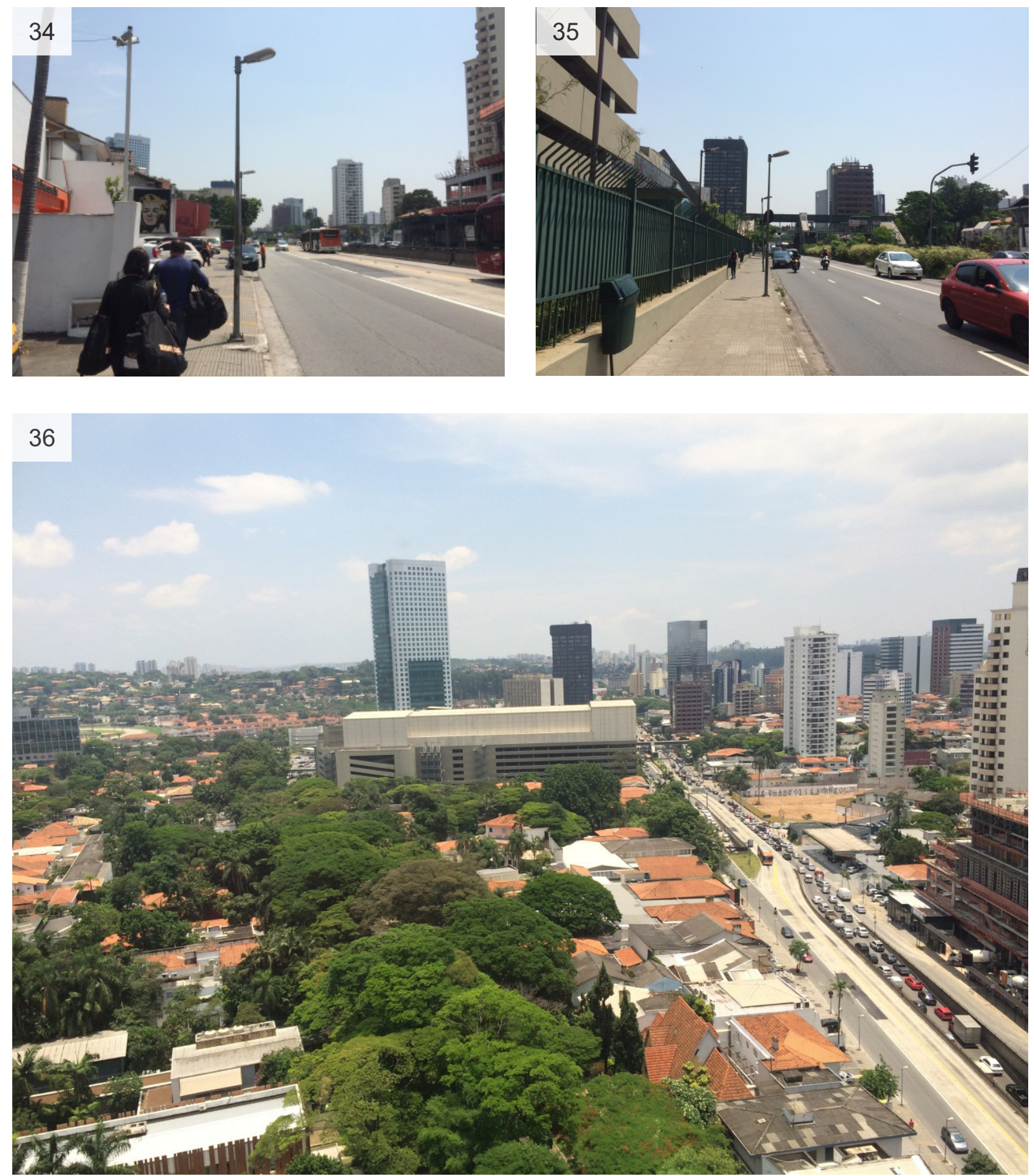

Figuras 34 e 35 - Av. Eusébio Matoso

Figura 36 - Vista superior da Av. Eusébio Matoso

Fonte: Fotos da autora 
$\mathrm{Na}$ Av. Eusébio Matoso nota-se o grande fluxo de carros e a pouca arborização inclusive nas calçadas, o gera um ambiente quente e desagradável em dias de sol. $\mathrm{Na}$ foto 28 , é possível ver o contraste dos altos edifícios e da cidade pouco arborizada do lado direito, e do lado esquerdo na Av. Rebouças a constância de casas e uma boa arborização proporcionando um ambiente muito mais confortável.

\section{Estação Ferroviária Hebraica-Rebouças, Av. das Nações Unidas}
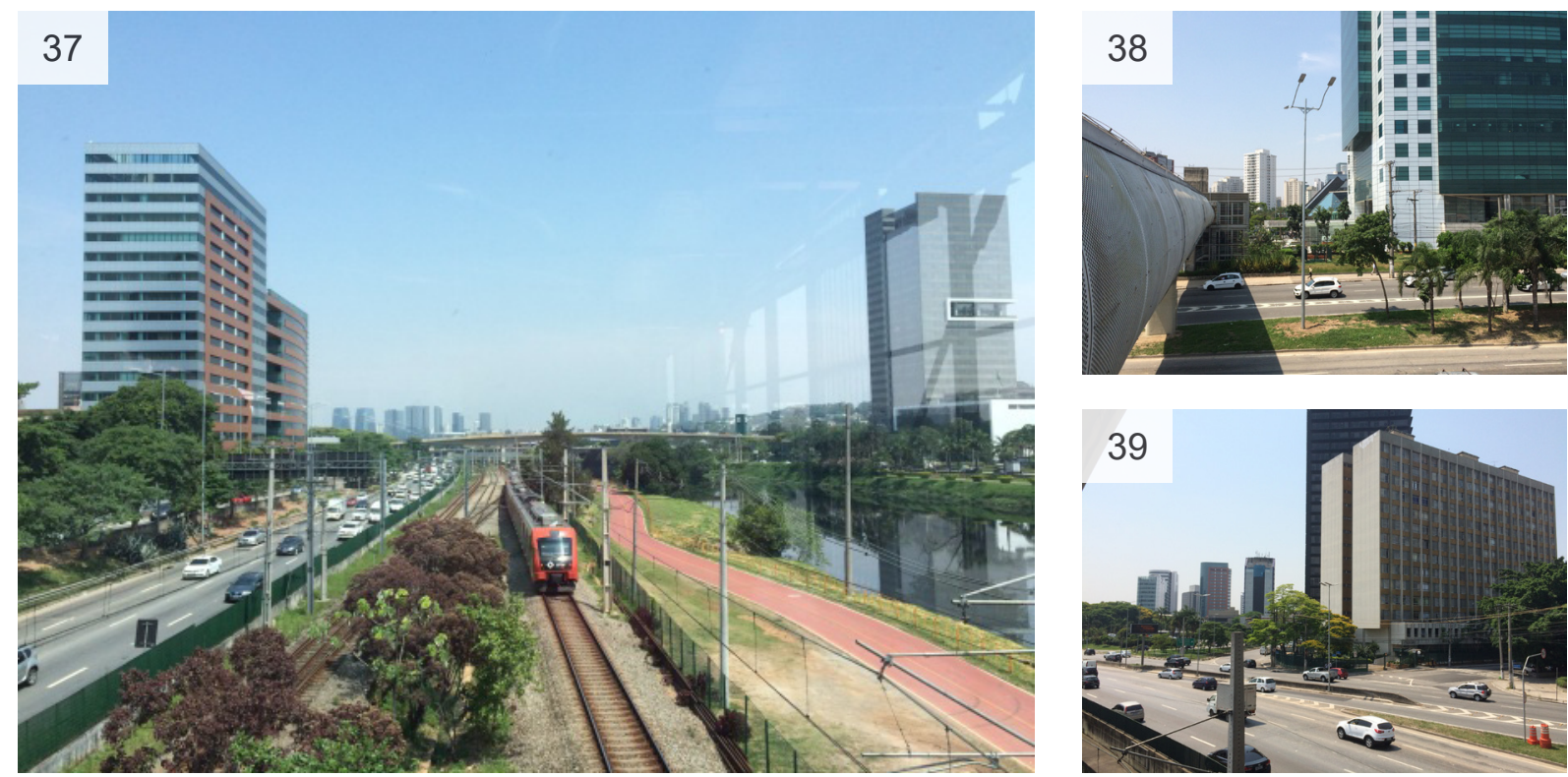

Figuras 37, 38 e 39 - Av. das Nações Unidas, Rio Pinheiros. Fonte: Fotos da autora

Av. Marginal do rio Pinheiros, Av. das Nações Unidas, ciclovia beirando o rio Pinheiros e a estação de trem Hebraica Rebouças. A ciclovia em grande parte não tem sombreamento, e o acesso se dá por passarelas, as calçadas na av. das Nações Unidas também tem pouca arborização, não tendo o conforto necessário para a circulação do pedestre.

\section{CONSIDERAÇÕES FINAIS}

Através da aplicação prática do estudo de insolação e sombreamento mostrados acima, nota-se a importância do conforto ambiental para o pedestre e como isso interfere na sua qualidade de vida no seu dia a dia. Sendo essa uma região de intenso fluxo de pedestre, de uso da calçada, de circulação dele ao seu trabalho, circulação desse 
pedestre para se alimentar durante o decorrer do dia, a grande área de comércio, as áreas de transporte público, estação de trem, metrô e ônibus demostram o quanto é importante à qualificação dessas áreas.

A análise da insolação nas diversas estações do ano feita nessa pesquisa no trajeto sugerido por uma centralidade de Pinheiros, que compreende o terminal Pinheiros, o metro Faria Lima à Avenida Rebouças e a estação de trem Hebraica Rebouças, mostram áreas desprotegidas, calçadas em poucos trechos com arborização.

Concentra-se o trecho com maior problema de intensa insolação no Largo da Batata, onde está à estação de metrô Faria Lima, essa praça que poderia ser um ambiente com qualidade ambiental, um ambiente agradável com conforto térmico, um lugar de respiro onde as pessoas gostariam de estar dentre tantas construções, não é caracterizado por essas atribuições, ele é um pátio aberto, sem sombreamento, um lugar de passagem onde todos querem passar bem rápido por conta do calor, ou chuva, não tem proteção climática gerada pelas árvores, é um ambiente vazio e desconfortável ao pedestre. Com as fotos expostas nesse trabalho e as simulações do sombreamento nas diversas estações do ano, comprovam tal desconforto.

E evidenciam a importância das estratégias de infraestrutura verde a serem aplicadas nos espaços de circulação.

\section{REFERÊNCIAS}

AMARAL, Antonio Barreto do. O bairro de Pinheiros. História dos bairros de São Paulo. São Paulo: Prefeitura Municipal - Secretaria de Educação e Cultura - Departamento de Cultura. 1969.

BRASIL. Edital do Concurso Público Nacional - Reconversão Urbana do Largo da Batata.

CESAD FAU-USP, DWG Gabarito de altura dos edifícios da cidade de São Paulo. Visita ao Laboratório de Geoprocessamento CESAD em outubro 2015.

COURMIER, N. Green Infrastructure: high performance landscapes for healthy cities. In: Discussão sobre inserção verde e drenagem urbana sustentável. SABESP, São Paulo, 2008. 
FIX, Mariana. Parceiros da Exclusão - duas histórias da construção de uma "nova cidade" em São Paulo: Faria Lima e Águas Espraiadas. São Paulo: Boitempo, 2001.

GONÇALVES S. C. J.; SHIZATO P.; SANCHES M. P.; FERREIRA S. L. Diretrizes de infraestrutura verde para o desenho urbano: Um exercício de planejamento paisagístico na área da Luz, São Paulo. Revista LABVERDE nº, 2013.

HEPNER, Alexandre. Desenho Urbano, Capital e Ideologia em São Paulo. Centralidades e forma Urbana na Marginal do Rio Pinheiros. USP, São Paulo 2010.

LEFEBVRE, Henri. O direito à cidade. São Paulo: Centauro editora, 2008, p.21 e 131.

MASCARENHAS, P. Luisa. Reconversão Urbana do Largo da Batata: Revalorização e novos conteúdos da Centralidade de Pinheiros. USP, São Paulo 2014.

SÃO PAULO. Concurso Público Nacional de Reconversão Urbana do Largo da Batata. 2002.

Sites

Prefeitura Municipal de São Paulo

http://www.prefeitura.sp.gov.br/cidade/secretarias/upload/desenvolvimento_urbano/arquivos/MDC.zip Base de 2005/2006.

http://www.prefeitura.sp.gov.br

http://www.prefeitura.sp.gov.br/cidade/secretarias/subprefeituras/pinheiros/ 